\title{
Dua Batu Berhias Dari Ruas Sungai Opak: Data Tambahan Pembangunan Percandian Prambanan
}

\section{Rita Margaretha Setianingsih}

Keywords: ornament, iconography, description, temples, hindu-buddha

\section{How to Cite:}

Setianingsih, R. M. (1998). Dua Batu Berhias Dari Ruas Sungai Opak: Data Tambahan Pembangunan Percandian Prambanan. Berkala Arkeologi, 18(1), 17-29. https://doi.org/10.30883/jba.v18i1.773

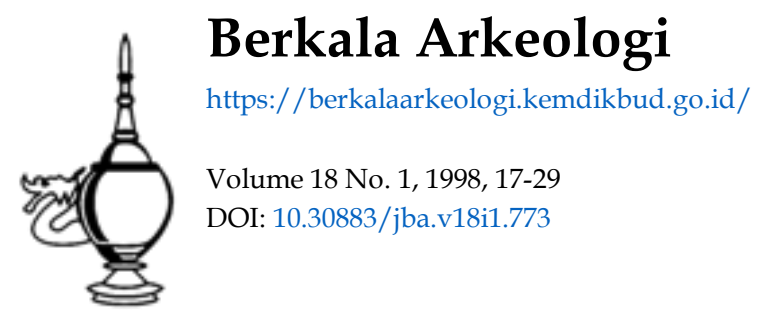

\section{c) (7) (2)}

This work is licensed under a Creative Commons Attribution-NonCommercial-ShareAlike 4.0 International License. 


\title{
DUA BATU BERHIAS DARI RUAS SUNGAI OPAK. DATA TAMBAHAN PEMBANGUNAN PERCANDIAN PRAMBANAN
}

\author{
Rita Margaretha Setianingsih \\ (Suaka Peninggalan Sejarah dan Purbakala Provinsi DIY)
}

Seizin no chiwa
Asahi tomo ete
Miyota kara kani
Nobi yuku Nippon
Aa awarera mikuni
No ta teso tsu yuki
ichi mon te tomo ni kita-en
chikara chikara kuruga neno chikara.'

\section{Pendahuluan}

Dua batu berhias ditemukan di ruas Sungai Opak, sekitar satu kilometer di sebelah barat daya kompleks Percandian Prambanan, masing-masing pada tahun 1976 dan 1997. Lokasi penemuan masuk dalam wilayah Dusun Randugunting, Desa Taman Martani, Kecamatan Kalasan, Kabupaten Sleman, DIY.

Satu sisi dari masing-masing temuan lepas yang terbuat dari batuan andesit berhiaskan goresan yang menggambarkan atribut dewa, lingkaran serta garis-garis lurus yang membagi lingkaran, serta bunga dan kelopak bunganya. Adapun pada temuan tahun 1976 terdapat pula hiasan berupa aksara Jawa Kuna. Keduanya menarik perhatian karena jarang ditemukan di Indonesia.

Pada tahun 1985 memang pernah ditemukan sebuah balok batu andesit berbentuk kubus di daerah Sumberharjo, Prambanan. Permukaannya juga berhiaskan goresan yang menggambarkan senjata tajam berupa pedang / kadga, anak panah / bana, tombak / sula, dan roda / cakra. Selain itu, di bagian samping gambar senjata tajam digoreskan pula aksara Jawa Kuna ( $s a, b a, t a . a)$, serta sebuah lubang berpenampang segitiga (trikoria). Mengenai obyek dari Sumberharjo ini, Kusen (1985) berpendapat bahwa gambar keempat jenis senjata tajam itu bukan merupakan atribut dewa-dewa

Terkenang kembali saat-saat pak Karto (panggilan akrab almarhum Drs. MM Sukarto Karto Atmodjo) menyanyikan lagu Jepang tersebut ketika mengantar kami para sisya yang belajar mengenal huruf-huruf yang sangat sulit dibaca langsung pada prasasti di lapangan. Beliau dengan suaranya yang lantang dan bariton memenuhi senyapnya lokasi yang dituju. 
dalam sistem astadikpalaka maupun nawasanga, melainkan atribut dari pañcabrahma sendirı

Bentuk dan goresan-goresan yang menghiasi kedua temuan dari Randugunting juga menarik perhatian karena memunculkan dugaan bahwa batu-batu tersebut merupakan penggambaran sebuah nawasanga atau yantra. Oleh karenanya lahir pula harapan mengenai adanya keterkaitan antara kedua obyek tersebut dengan pembangunan kompleks percandian Prambanan. sebagaimana yang akan dicoba untuk ditelusuri dalam tulisan sederhana ini

\section{Sekilas temuan dari ruas Sungai Opak}

\section{II.1. Batu berhias BG. 748}

Batu berhias yang ditemukan tahun 1976 ini sekarang disimpan di Kantor Suaka Purbakala Peninggalan Sejarah Provinsi DIY dengan nomor koleksi BG. 748. Bentuknya bulat bergaris tengah $38 \mathrm{~cm}$ dengan tebal $4,50 \mathrm{~cm}$.

Goresan yang menghiasi hanya satu bidang permukaannya itu membentuk adanya empat buah lingkaran (lihat gambar 1). Lingkaran pertama yang berada di tengahtengah berisi tulisan yang membujur dari kiri ke kanan dan masing-masing berbunyi ña. ma. dan $k h a^{2}$ Di bagian bawah tulisan itu terdapat hiasan berupa gambar vajra untuk ña, Irisula untuk ma, dan padma dengan delapan helai kelopak bunga untuk $k h a^{3}$

Lingkaran kedua, ketiga, dan keempat, masing-masing terbagi menjadi sembilan tembereng oleh adanya sembilan garis lurus yang terpancar dari sisi luar lingkaran pertama. Jadi seluruh permukaan batu berhias itu terbagi atas 27 buah tembereng serta sebuah lingkaran di bagian tengah.

Dalam tiap-tiap tembereng juga digoreskan hiasan dan tulisan. Pada temberengtembereng di lingkaran kedua, hiasannya berupa gambar trisula yang berdampingan dengan huruf $m a$. Selanjutnya pada lingkaran ketiga, hiasannya berupa gambar vajra dengan tulisan $\tilde{n} a$. Dan di tembereng-tembereng pada lingkaran keempat dipenuhi oleh gambar paidma dengan delapan helai kelopak bunga dan tulisan kha.

Berdasarkan bentuk hurufnya saja sulit untuk mengetahui angka tahun yang tepat. namun jelas berasal dari masa Klasik Jawa Tengah. 


\section{II.2. Batu berhias BG. 1521}

Batu berhias temuan tahun 1997 ini juga disimpan di SPSP DIY dengan nomor koleksi BG. 1521. Bentuknya persegi empat dengan ukuran $57 \mathrm{~cm} \times 56 \mathrm{~cm}$ dengan ketebalan $12 \mathrm{~cm}$.

Goresan yang menghiasi obyek ini juga hanya terdapat pada satu bidang permukaan saja. Namun berbeda dengan batu berhias BG. 748, koleksi BG. 1521 hanya memiliki sebuah lingkaran saja. Lingkaran itu berada di bagian tengah bidang permukaan dan terbagi menjadi sembilan kotak olch adanya empat buah garis yang saling berpotongan (lihat gambar 2).

Kotak di bagian tengah lingkaran berhiaskan sembilan bunga yang masing-masing memiliki empat kelopak bunga. Masih dalam lingkaran terscbut, pada kotak-kotak di arah mata angin utara, timur, selatan, dan barat terdapat pula hiasan berupa dua buah vajra yang mengapit bunga dengan empat kelopaknya. Kemudian, pada kotak-kotak di arah mata angin timurlaut, tenggara, baratdaya, dan baratlaut digoreskan tiga buah bentuk vajra

Selanjutnya, mengelilingi lingkaran pada bagian luarnya dipahatkan bentuk-bentuk ankusa, vajra, dupa, danda, musala, naga, sanka (?), dan gada.

\section{Nawasanga dan yantra pada batu berhias}

Nawasanga merupakan konsep tata ruang kedewaan yang terbagi atas sembilan bagian, dimana delapan bagian mengelilingi sebuah ruang di bagian tengah. Delapan ruang itu masing-masing ditempati olch dewa-dewa Lokapala. Adapun di bagian pusat ditempati oleh Siwa, di timurlaut olch Sambhu, timur - Iswara, tenggara - Mahesàwara, selatan - Brahma, baratdaya - Rudra, barat - Mahadewa, baratlaut - Shangkara (Pott, 1966: 135)

Dalam mitologi Hindu, dewa digambarkan berdiri atau duduk di atas padmasana yang memiliki daun delapan lembar. Ini melambangkan delapan dewa yang menguasai delapan penjuru mata angin. Maka penggambaran padma yang memiliki delapan kelopak/daun bunga merupakan lambang dewa Nawasanga atau Nawadewata. Nawadewata sendiri merupakan sembilan aspek Siwa yang selalu dikaitkan dengan dewa-dewa penguasa sembilan arah mata angin.

Konsep nawasanga rupa-rupanya diterapkan di Candi Merak, dimana puncak candi menampakkan tokoh Paramasiwa yang disertai pula oleh dewa-dewa yang menyertainya (Soekmono,1974). Begitu pula halnya dengan Candi Prambanan, 
dimana penerapan konsep nawasanga terlihat dengan ditemukannya prasasti pendek yang menyebutkan bahwa penguasa sisi barat adalah Siwa dalam kedudukannya sebagai Siwa Mahadewa (Setianingsih, 1995).

Pada bagian batu penutup sungkup Candi Ngrimbi ditemukan pula atribut dari masing-masing Nawadewata/Nawasanga. Batu penutup sungkup itu berbentuk segiempat berhiaskan lingkaran dengan delapan kelopak bunga. Setiap kelopak bunga dilengkapi vajra - Iswara/timur, dupa - Maheswara/tenggara, danda Brahrna/selatan, musala - Rudra/baratdaya, naga/pasa - Mahadewa/barat, ankusa Sankara/baratlaut, gada/cakra - Visnu/utara, trisula - Sambhu/timurlaut dan pusat padma yang ditempati oleh Siwa (Pott,1966: 133).

Penggambaran dewa-dewa yang duduk dalam nawasanga dengan masing-masing atributnya ditemui pula pada temuan BG. 1521. Siwa digambarkan berada di bagian pusat dengan atribut padma. Hal ini juga tampak melalui penggambaran pada batu berhias itu dimana bagian pusatnya yang berupa kotak berisikan sembilan padma berdaun bunga empat helai. Namun berdasarkan pengamatan akan hal ini, penulis berkesimpulan bahwa bila atribut-atribut tersebut berkenaan dengan dewa-dewa nawasanga maka terdapat beberapa kejanggalan. Kejanggalan pertama berupa penggambaran danda/tongkat dan musala /alu. Pada batu berhias itu danda digambarkan sebanyak tiga buah, musala digambarkan enam buah, dan di bagian pusat/Siwa digambarkan melalui atribut padma berjumlah sembilan buah. Kejanggalan kedua tampak pada penggambaran ankusa dan sanka(?) yang tidak sama dengan posisi kedudukan dari dewa nawasanga. Dalam konteks ini seharusnya sisi timurlaut ditempati oleh dewa Sambhu yang bersenjatakan trisula, dan tidak seperti pada pada batu berhias BG. 1521 yang sisi timurlautnya justru ditempati oleh ankusa milik dewa Sangkhara yang seharusnya berada di sisi baratlaut.

Pada umumnya atribut dewa digambarkan hanya sebuah saja. Namun tidak demikian halnya pada penggambaran sebuah yantra ${ }^{3}$ dimana sering pula atribut dewa, seperti trisula, digambarkan dalam jumlah lebih dari satu. Ini terlihat misalnya pada penggambaran Bagalamukhidharanayantra dimana trisula digambarkan sebanyak delapan buah dan menduduki setiap arah mata angin dengan kotak yang terdapat 'Lam' (Pott, 1966: 34).

Yantra berarti 'penolong' atau 'alat' dan biasanya digunakan oleh para yogi sebagai penolong di dalam meditasi dan juga dalam hal-hal tertentu dapat digunakan sebagai wadah dari istadewata, tetapi yantra ini dapat pula dikategorikan sebagai diagram mistik. Ada beberapa bentuk dari yantra, seperti bindu, catuskona, ganapati, yantra, mandala, mukti. padma dan sebagainya (Liebert, 1976: 352). 
Atribut dewa yang digambarkan pada bagian luar lingkaran batu berhias BG. 1521 jelas merupakan penggambaran atribut dewa Siwa, karena Siwa dengan segala aspeknya sering digambarkan memegang atribut gada. pasa. Irisula, naga, ankusa. vajra. danda. musala dan sanka. Dari beberapa atribut dewa Siwa ini hanya atribut dupa dalam goresan BG. 1521 yang tidak termasuk dalam atribut Siwa. Begitu pula pada batu berhias BG. 748, dimana digambarkan irisula, vajra dan padma dengan masing-masing pasangannya yang berupa aksara.

Di dalam mitologi Hindu, trisula dan vajra merupakan atribut untuk dewa Siwa dan padma adalah atribut untuk dewa Brahma dan Siwa. Dalam nawasanga. trisula merupakan atribut dari dewa Sambhu, vajra adalah atribut dari Iswara dan padma adalah juga atribut dewa Siwa. Diketahui bahwa nawasanga merupakan sembilan aspek atau jelmaan Siwa. Oleh karena itu dapat disebutkan pula bahwa vajra dan padma diperuntukkan bagi dewa Siwa.

Kata ñama yang dijumpai pada batu berhias BG. 748 merupakan ajaran yoga dimana para yogi harus melakukan yoga yang didapat dengan melatih pikiran untuk tidak terpaut pada obyek keinginan hawa nafsu. Pada prinsipnya yoga mengajarkan delapan macam disiplin untuk mencapai tingkat kesucian batin, masing-masing adalah: yana, yaitu latihan menahan penderitaan hidup/hawa nafsu ketamakan; nyama, kesusilaan dengan melakukan perbuatan baik/renungan terhadap Tuhan; asana, mengambil sikap badan yang baik; pranayama, pengaturan nafas; pratyahara, pengendalian terhadap indera; dharana, membawa pikiran pada satu obyek; dyana, meditasi terhadap satu obyek; samadhi, lenyapnya kesadaran dan renungan yang mendalam pada satu obyek dan tak sadar lagi akan dirinya (Gede,1982). Sebagai penolong di dalam menaklukan kekuatan-kekuatan jahat yang ada dalam diri manusia, para yogi menggunakan sarana dalam bentuk yantra.

Adapun kata kha merupakan sebuah simbol dari sankhya yang berhubungan dengan kedudukan bulan dan bintang/naksatra yang berjumlah 27, dan kadang-kadang ada yang berjumlah 28 (Liebert, 1976: 189). Angka 27 dapat dihubungkan dengan jumlah pembagian ruang/tembereng dalam batu berhias BG. 748. Bagian pusat BG. 748 yang berbentuk lingkaran (bundar)dapat disejajarkan dengan bulan/candra. Hal inipun berkenaan dengan candra-mandala yang merupakan salah satu yantra yang merupakan sifat yang khas dari Siwa (Liebert, 1976: 55).

Dalam Siwa Purana digambarkan bagaimana candra berhubungan dengan Siwa karena candra merupakan salah satu nama/aspek dari Siwa (Shastri,1974: 1402). Bagian pusat diibaratkan sebagai Gunung Meru, tetapi kadang-kadang juga diperuntukkan bagi Buddha atau dewa yang dalam bentuk damai (Gibson, 1996: 83). 
Pada masa Mataram Kuna, agama Siwa yang berkembang di Jawa Tengah merupakan agama Siwa yang bersumber pada Siwa Purana dan Siwa Upanisad (Santiko, 1996: 145). Berdasarkan kitab Purana diketahui bahwa dalam aliran Saiwa kedudukan terpenting ditempati oleh Siwa (Paramasiwa). Siwa merupakan realitas tertinggi dan bersifat satcitananda (sat - keberadaan; cit - kesadaran; dan ananda - kebahagiaan). Siwa adalah segala sesuatu dan merupakan bentuk halus yang terdiri dari lima mantra yang membentuk kekuatan, sehingga Siwa mempunyai tugas utama sebagai pengatur angkasa (pacabrahma) dan pengatur lima tindakan/kekuasaan (pancakritya).

Adapun aliran Saiwa Siddhanta mengganggap Siwa sebagai Dewa tertinggi dan yang mempunyai tiga macam penjelmaan untuk menguasai alam semesta. Sebagai ParamaSiwa, ia mempunyai sifat niskala(tanpa ujud tanpa bentuk) dan berkedudukan di zenith, ${ }^{4}$ dan sebagai Sada-Siwa ia bersifat sakala-niskala (sesekali menampakkan ujud dan bentuk sebagai penyelamat manusia yang akan mencapai moksa), dan berkedudukan di pusat. Sedangkan sebagai Maheswara, ia mewakili segala ujud dan bentuk dunia fana ini dan berkedudukan di nadir (Pott, 1940: 119).

Adanya tiga dunia yang masing-masing dikuasai oleh salah satu bentuk dewa Siwa itu tergambarkan pula pada ujud bangunan candi, yang dari bawah ke atas terdiri dari kaki, tubuh dan atap. Ketiga bagian bangunan itu berturut-turut melambangkan bhurloka, bhwarloka dan swarloka (Stutterheim,1937: 245). Maka candi sebagai bhurloka merupakan dunia yang dikuasai Mahecwara, tubuh candi sebagai bhuwarloka dikuasai Sada-Siwa dan atap candi sebagai swarloka merupakan daerah yang dikuasai Parama-Siwa. Parama-Siwa ini disertai oleh delapan pengiring yang kesemuanya tidak lain adalah jelmaan dari Siwa sendiri. Kedelapan dewa itu disebut astadewata dan bersama dengan Parama-Siwa sendiri menjadi nawadewata atau nawasanga. Dalam nawasanga atau nawadewata ini, bagian sisi barat dikuasai oleh Siwa Mahadewa.

\section{Vastupurusamandala dalam pembangunan candi}

Candi-candi Hindu-Budha di Jawa Tengah menggunakan diagram Vastupurusamandala sebagai dasar/pedoman penyusunan tata letak kompleks percandian. Vastupurusamandala merupakan sebuah yantra yang digambarkan sebagai bujur sangkar yang dibagi lagi dalam bujur sangkar-bujur sangkar yang lebih kecil. Diagram vastupuru samandala berfungsi sebagai rancangan metafisika bangunan candi, tata letak (site plan) candi, istana, dan kota (Anom, 1997: 386,444). Dalam kaitannya dengan itu, pengamatan Anom sampai pada kesimpulan bahwa tata

4 Zenith adalah titik pada bola ruang angkasa yang terletak tepat di atas kepala pengamat. Lawannya adalah nadir, titik yang terletak tepat di bawah kaki. 
letak kompleks percandian Lorojonggrang menggunakan diagram Vastupurusamandala, yakni dalam tipe diagram paramasayika.

Di tempat asal Hindu-Budha, aturan dalam membuat kuil teicantum dalam banyak karya sastra, diantaranya adalah Manasara, Mayamata, Silpasastra, dan Visnudhamotaram. Dalam kitab-kitab Manasara dijelaskan tentang adanya ada tahapan dalam mempersiapkan segala sesuatu yang diperlukan untuk mendirikan kuil/candi, mulai dari pemilihan lahan, penentuan titik pusat halaman, pembuatan diagram dan pemberian pendeman/peripih

Syarat utama yang dipentingkan dalam mendirikan bangunan suci adalah letaknya di daerah yang ada airnya (tirtha), terutama di dekat pertemuan dua sungai. Selain itu tempat lain yang baik untuk mendirikan kuil menurut Tantra Samuccaya adalah di puncak bukit, di lereng gunung, di dalam hutan, dan di lembah (Kramrisch, 1946: 1,3$-7)$.

Selanjutnya adalah upaya dalam pemilihan lahan dengan memperhatikan akan jenis tanah yang baik. Dalam Silpa Prakarsa disebutkan bahwa pengujian tanah dapat dilakukan pula dengan menggunakan nyala minyak, perhitungan astrologi, dan juga berdasarkan sangku/gnomon. ${ }^{6}$ Dicontohkan apabila nyala apinya tegak atau miring dan langsung mengerah ke utara, tempat di mana Kuwera berada, berarti tanah itu baik. Secara astrologi, pembangunan tidak diijinkan pada tanggal-tanggal rikta (kosong) dan periode celaka (karana). Adapun tanah yang baik menurut pengujian dengan sangku apabila sangkunya bergerak lebih panjang, dan menimbulkan bau harum. Sebaliknya bila sangkunya bergerak lebih pendek dan menimbulkan suara ramai, maka tanah tersebut harus dihindari.

Kembali ke nusantara, kita dapat meraba bahwa aplikasi aturan-aturan suci itu juga berlangsung. Dalam prasasti Siwagrha disebutkan bahwa dalam pembangunan rumah yang diperuntukkan bagi dewa Siwa, sebuah aliran sungai dipindahkan karena

5 Berdasarkan penuturan kitab Manasara, diagram dengan 64 kotak adalah tipe chandita sedangkan diagram dengan 81 kotak adalah tipe paramasayika. Tetapi menurut keterangan yang diberikan Anom. diagram dengan 64 kotak adalah diagrain paramasayika

5 Gnomon atau sangku adalah sebuah tongkat yang ditancapkan tegak lurus tepat di tengahtengah bidang tanah yang telah diisi benih, sebagai titik sumbu. Dari titik sumbu dibuatlah sebuah lingkaran berjari-jari dua kali panjang tongkat gnomon tersebut, yang kemudian ditentukan titik jatuh bayangannya (apachaya). Selanjutnya ditentukan pula titik jatuhnya bayangan pada pagi dan sore hari, dan kedua titik tersebut dihubungkan hingga menjadi sebuah garis. Dari titik ini dibuatlah lingkaran yang akan menghasilkan titik potong dan jika dihubungkan akan membentuk bujur sangkar. 
menyentuh tanah yang justru akan menjadi tempat berdirinya bangunan itu. Nitihaminoto dalam penelitiannya melihat bahwa ruas Sungai Opak pernah melebar sampai 200 meter ke sebelah timurnya, dan berkesimpulan bahwa kompleks Candi Prambanan dibangun setelah aliran Sungai Opak surut ke barat beberapa waktu lamanya, serta dibangun di atas bekas endapan sungai. Ada kemungkinan bahwa pelebaran sungai Opak tersebut diibaratkan sebagai sebuah dam (tamwaka) seperti yang termuat dalam prasasti Siwagrha. Tambak atau dam tersebut terbuat dari batu bata yang harus ditimbun jika tanah tersebut nantinya digunakan sebagai percandian Pengurukan tanah itu kira-kira setebal 10-50 cm (Nitihaminoto, 1997: 116).

Dimungkinkan bahwa pemindahan aliran Sungai Opak tersebut berkenaan dengan upaya pemilihan lahan, pengujian tanah dan penentuan diagram. Aliran sungai tersebut dipindahkan pada tahun 778 Saka (wualung gunung sang wiku), pada saat arca dewa telah selesai dikerjakan, bahkan telah ditahbiskan. Kesemuanya itu dilakukan setelah tanah dipilih dan dianggap sudah tidak ada ancaman lagi dari kejahatan. Tanah yang dipilih tersebut ditahbiskan menjadi tanah suci. Pada awalnya tanah yang dibuat bangunan suci tersebut luasnya dua tampah dan dimiliki oleh Pameget Wantil dengan nayaka dan patih-nya. Sesudah tanah bekas sawah tadi ditahbiskan dan menjadi tanah yang bebas (telah diuji dan terbebas dari kejahatan), maka tanah tersebut menjadi milik dewa. Selanjutnya barulah proses pendirian bangunan suci bagi dewa Siwa atau Siwagrha itu dilanjutkan.

Jadi setelah pemilihan lahan dilakukan, dibuatlah diagram yang biasanya digambarkan langsung di atas tanah, juga dengan maksud menyucikannya. Diagram ini yang dikenal sebagai diagram vastupurusamandala.

Bosch pernah memperkirakan bahwa dalam pembangunannya, Candi Sewu menggunakan diagram Vajradhatu-mandala (diagram Budha) (1962: 124-130). Demikian pula dengan Candi Gumpung, dimana pusat kaki candinya merupakan bangunan bata mirip kubus yang ukuran panjangnya adalah enam meter yang tepat di bawahnya terdapat 11 lubang yang disusun demikian rupa sehingga sebuah lubang pusatnya berukuran $1 \mathrm{~m} \times 1 \mathrm{~m}$. Lubang pusat ini dikelilingi empat lubang lain pada sumbunya, masing- masing berukuran $0,20 \mathrm{~m} \mathrm{x} 0,20 \mathrm{~m}$., dan dua di sudut baratlaut dan timurlaut yang masing-masing berukuran $0,20 \mathrm{~m} \times 0,20 \mathrm{~m}$ dan $0,15 \mathrm{~m} \times 0,15 \mathrm{~m}$.

Susunan demikian sesuai dengan Vajradatumandala. Salah satu isi peripih tersebut adalah lempengan emas bertuliskan nama dewa yang diawali dengan perkataan vajra. Ini mengingatkan pada nama-nama dewa yang tergabung dalam pantheon

Kejahatan dimaksud dapat berupa kekuatan magis maupun nyata. Tertuang dalam Manasara bahwa untuk menghindari bahaya dapat dilakukan dengan cara menggeser bangunan bila bangunannya menurut rencana harus berdiri di tengah lapangan. 
Vajradathumandala yang jika lengkap terdiri atas 37 dewa, yakui: 5 Tathagata, 16 Vajrabodhisatwa dan 16 Wajratara. Menurut Vastusastra diagram ini dapat pula digunakan sebagai denah kuil/candi. Dalam hal ini Hariani Santiko menyebutkan bahwa diagram Vastupurusamandala digunakan dalam pembangunan candi-candi di Jawa dan tidak digunakan sebagai denah halaman maupun denah kuil.

Berdasarkan itu dapat disebutkan bahwa diagram vastupurusa mandala dengan tipe diagram paramasayika yang diterapkan di percandian Prambanan tidak berkaitan dengan keberadaan batu berhias dari ruas Sungai Opak di Randugunting. Penggambaran penggambaran diagram paramasayika menggunakan 81 kotak sedangkan goresan dalam batu BG. 1521 hanya menghasilkan 17 buah kotak.

\section{Penutup}

Dua batu berhias dari Sungai Opak menarik untuk dicermati. Hingga saat ini terlihat bahwa masing-masing mempunyai fungsi dan makna yang berbeda. Batu berhias BG. 748 yang memuat atribut-atribut dewa, yakni vajra, trisula dan padma yang kesemuanya dapat dihubungkan dengan Siwa. Demikian pula dengan aksara Jawa Kunanya yang menyebutkan ña-ma - kha. Kata ñama berhubungan dengan para yogi untuk mencapai tingkat kesucian batin dengan melakukan perbuatan baik dan perenungan mengenai Tuhan. Para yogi melakukannya dengan menggunakan sarana yang disebut sebagai yantra. Demikian pula dengan tulisan kha yang merupakan simbol dari sankhya yang berkenaan dengan kedudukan bulan dan bintang yang berjumlah 27 buah, sesuai pula dengan jumlah tembereng BG. 748. Lingkaran di bagian tengah dapat melambangkan candra, sehingga memungkinkan apabila BG. 748 merupakan candramandala yang merupakan salah satu yantra sekaligus gambaran sifat khas dewa Siwa.

Batu berhias BG. 1521 menggambarkan atribut dari dewa-dewa nawasanga, sebagaimana pusat lingkaran di tengah permukaan batu tersebut yang dibagi menjadi 9 kotak berhiaskan padma. Juga goresan lain yang merupakan atribut bagi dewa Siwa. Penggambaran dewa Siwa sebagai Paramasiwa yang disertai delapan pengiring (yang tak lain adalah Siwa itu sendiri) dapat dihubungkan dengan percandian Prambanan. Siwa dianggap sebagai Siwa Mahadewa, sebagai penguasa sisi barat dan penguasa di pusat diduduki oleh Paramasiwa.

Menutup tulisan singkat ini, seandainya benar dugaan bahwa kedua batu berhias dari ruas Sungai Opak tersebut merupakan candramandala (BG. 748) dan nawasanga (BG. 1521), pertanyaan lain yang muncul berkenaan dengan keberadaannya di tempat penemuan. 
Sebclum pagar keliling ketiga kompleks percandian dibuat, Sungai Opak permah melebar ke arah Timur selebar 200 meter Oleh karena itu, kemungkinan besar karena kuatnya aliran sungai maka batu-batu candramandala dan nawasanga tersebut bergeser cukup jauh. sekitar satu kilometer ke arah baratdaya hingga ke lokasi pencmuannya kembali pada tahun 1976 dan 1997.

\section{KE PUST AKAAN}

Acharya, PK. 1933. Indian Architecture According to Manasara-Silpasastra. Volume I, IV. Oxford University Press

Anom, I Gusti Ngurah, 1997 Keterpaduan Aspek Tehnis Dan Aspek Keagamaan Dalam Pendirian Candi Periode Jawa Tengah (Studi Kasus Candi Utama Sewu). Desertasi: Universitas Gadjah Mada, Yogyakarta.

Casparis. JG de. 1956. Selected Inscription from the 7th to 9th Century AD. Prasasti Indonesia II. Bandung: Masa Baru.

Gibson. Clare, 1996. Sign \& Symbols. An illustrated Guide to Their Meaning and Origins. London: Grange Books

Kramrisch, Stella. 1946. The Hindu Temple. Vol. I. Calcutta: University of Calcutta

Kusen, 1985. Sekelumit Data Tentang Pancabrahma Dalam Periode Klasik Jawa Tengah. makalah dalam Kegiatan llmiah Arkeologi, IAAI Kom isariat Yogyakarta Jawa Tengah di Yogyakarta

Liebert. Gosta, 1976. Iconograhic Dictionary of the Indian Religions. Hinduism Buddhism - Jainism. Leiden: E.J. Brill

Nitihaminoto. Goenadi. 1977. Pembangunan Kompleks Candi Prambanan. Tinjauan Atas Lapisan Tanah, dalam: Inajati Adrisijanti Romli dkk. (eds.), Cinandi. Yogyakarta: Jurusan Arkeologi Fakultas Sastra UGM, hat. 113-117.

Pott,H .. 1966. Yoga and Yantra (Translation Series 8). The Hague: Martinus Nijhoff Pudja, Gede. 1982. Bhagavadgita (Pancama Weda). Jakarta: Mayasari 
Santiko, Hariani, 1996. Seni Bangunan Sakral Masa Hindu-Buddha di Indonesia (Abad VII - XV Masehi): Analisis Arsitektur don Malmo Simbolik, dalam:Jurnal Arkeologi Indonesia. Jakarta: Puslitarkenas, hal. 136-156.

Setianingsih. Rita Margaretha, 1 995. Lempengan Emas Bertulis dari Candi, dalam: Hariani Santiko dkk. (eds.), Kirana: Persembahan untuk Pro f. Dr. Haryati Soebadio. Jakarta: PT lntermasa, hal. I 60-169

Shastri. JL. 1974. Ancient Indian Tradition \& Mytolog y. Vol. IIDelhi: Motilal Banarsidas

Soekmono, 1974. Candi Fungsi don Pengertiann ya. Desertasi Universitas Indonesia, Jakarta. 


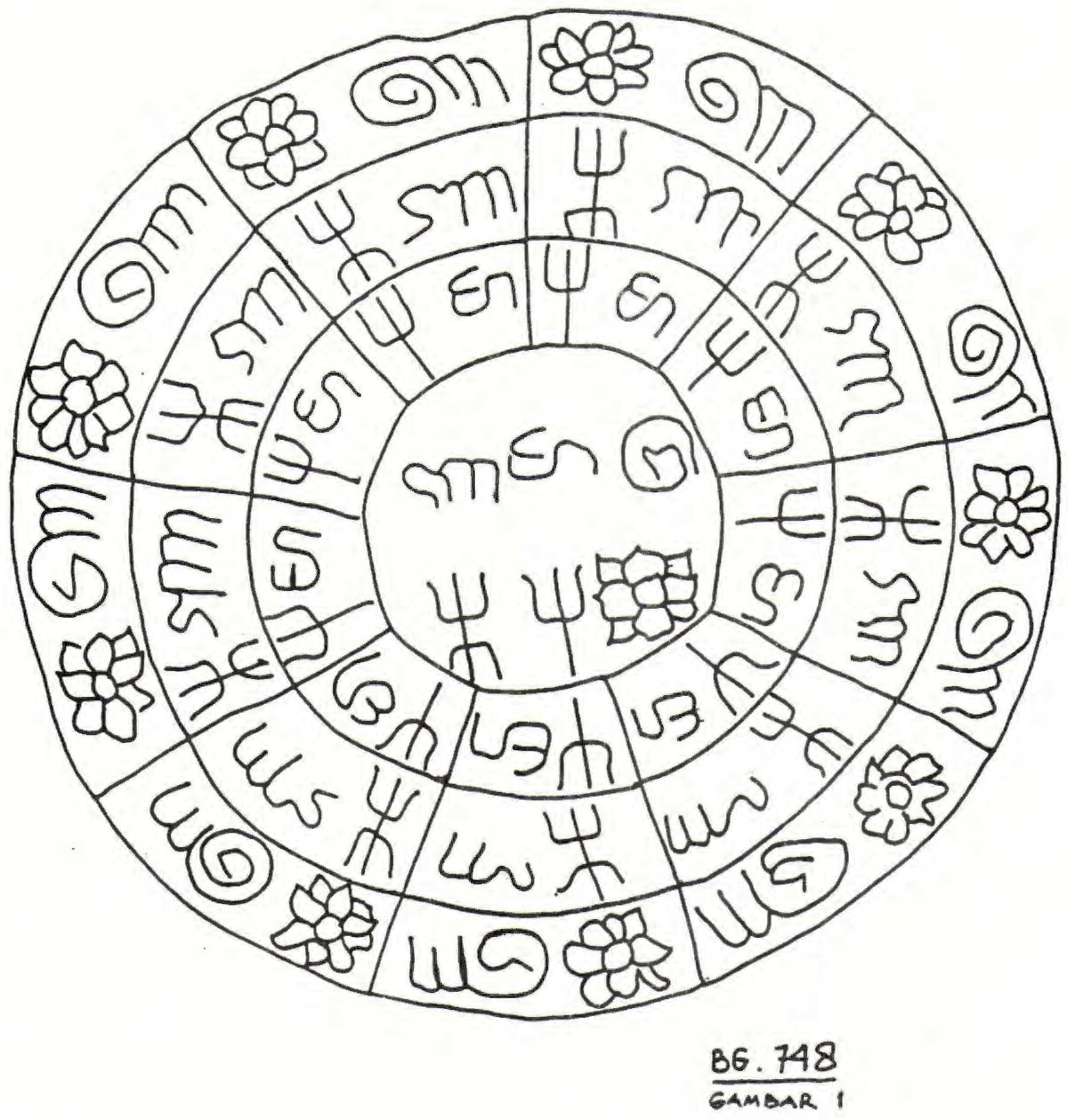




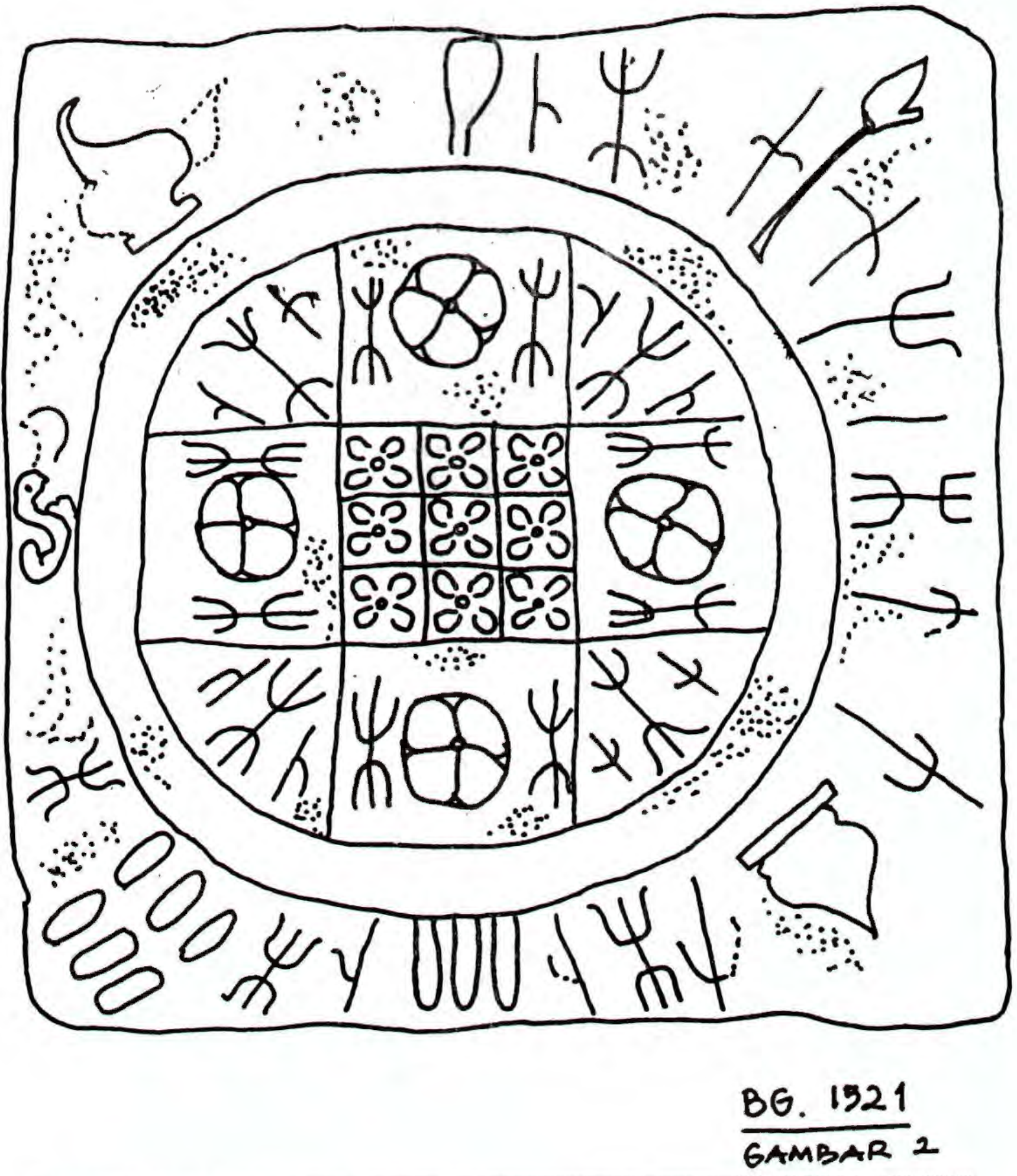

